In Focus

\title{
Distributor Strategies in the Face of Closed Cinemas: Norwegian Responses to Covid-19
}

$\$$ sciendo

MARIUS ØFSTI, Inland Norway University of Applied Sciences, Norway; email: olav.marius.ofsti@inn.no 


\begin{abstract}
This article examines the choices made by Norwegian distribution companies during three key phases of cinema lockdown and reopening in 2020. Though the article mainly aims to chronicle this particular moment in time I find that Norwegian and Scandinavian VOD-services acted differently than international services and that, while distributor companies used several different strategies in the face of sudden change, no one was close to recouping the losses from the lack of ordinary cinematic exhibition.
\end{abstract}

\section{INTRODUCTION}

When Covid-19 caused cinema closings all over the world, film distributors faced the choice between waiting or going "straightto-video"1. Hollywood Studios such as Universal, and later Disney, decided to release major titles to Premium Video-on-Demand (PVOD) services, while others are still waiting to see if cinemas will recover (McClintock 2020). Nevertheless, many question whether cinema exclusivity is becoming a thing of the past and that only the biggest of titles will remain in cinemas (Ide 2020, Skagen 2020).

This article examines the strategic responses of Norwegian film distributors from the immediate reactions to closed cinemas in March 2020, and the first Norwegian PVOD releases, to the "new normal" of reduced capacity and few international titles in the fall of 2020.

\footnotetext{
In this article I use the terms preferred by the industry: $V O D=$ Video-on-demand.

EST = Electronic-sell-through, the customer pays a one time fee for unlimited access and/or downloads of a given title.

TVOD = transactional video-demand, the customer pays for a limited (usually 24/48 hours) access to a given title.

$P V O D=$ premium video-on-demand, the customer pays for a limited (usually 24/48 hours) access to title, but at an earlier point in the films life-cycle and at a significantly higher price point.

SVOD = subscription video-on-demand, the customer pays a monthly fee to access a number of films and/or tv-shows.
}

\section{BACKGROUND}

Film distribution companies are generally described as intermediaries between the film production companies that produce movies and cinemas, stores and platforms that sell or exhibit movies. Distributors essentially turn each individual film into a product that can be sold or rented. This includes the actual delivery of prints or files, as well as marketing (Crisp 2015).

In Norway, we find three kinds of distributors including subsidiaries of Hollywood studios, subsidiaries of Scandinavian studios, and independent Norwegian distributors (Skei 2010). Of these only the latter two kinds of companies regularly invest in Norwegian movies, and only the two Scandinavian subsidiaries, SF Studios and Nordisk Film Distribusjon, regularly invest in high budget market-oriented movies. ${ }^{2}$ In addition to investing in local titles all Norwegian distribution companies acquire rights to foreign titles, either through output deals with studios or by purchasing individual rights.

A key strategy in film distribution is windowing the staggered release of a single title from high paying cinema exhibition to the lower paying Electronic Sell-Through

$2 \quad$ Norwegian high-budget titles tend to have a budget between 5 and 7 million Euro and will typical target $350000+$ tickets sold domestically. 
(EST), Transactional Video-on-Demand (TVOD) and finally television or Subscription Video-on-Demand (SVOD) windows. In the last five years Norwegian titles usually have at least around 90 days from cinematic premiere to DVD release, but this varies between distributors. ${ }^{3}$ EST releases tend to come around 7 to 21 days before the DVD release and the TVOD release. Various SVOD and television windows tend to open one year after the cinema premiere and, depending on the service and deals made by the distributor, move from higher-paying to lower-paying services over the next few years. With the exception of a brief period where DVD sales were very high, cinemas have remained the main source of income for movies in Norway (Gaustad et al. 2018).

Norway is a small market for movies and the film industry and, like other small nations, is dependent on government support schemes (Hjort and Petrie 2007, Bakøy, Puijk, and Helseth 2016). However, the distributors are the main private investors in local titles and are likely to invest between 150000 and 1000000 euro in a title (Gaustad et al. 2020). For local titles they act as first-run distributors (Lotz 2019) and generally acquire both cinematic and home entertainment distribution rights.

All Norwegian distributors also acquire international titles, either through outputdeals or individual purchases. These acquisitions are considered relatively safe investments compared to local titles. Depending on the title or deal, the Norwegian distributor might acquire cinematic and/or home entertainment distribution rights.

\section{METHODS}

When Covid-19 caused cinemas to close, it also interrupted my ongoing PhD thesis on the challenges Norwegian film distributors are facing in the digital film markets. As a part of this work, I was conducting regular

According to DVD release dates provided by leading retailer Platekompaniet in the period 2013 to 2018 , Nordisk Film Distribusjon had windows ranging from 45 to 367 days (for christmas movies) and averaged 120 days, SF Studios ranged from 45 to 202 days and averaged 99 days, and Norsk Filmdistribusjon ranged from 122 days to 248 days and averaged 171 days. qualitative interviews with several key distributors in Norway as well as collecting quantitative data from various public and private sources and tracking the visibility of Norwegian movies across a number of VOD platforms.

This article was bolstered with interviews with further Norwegian distributors to include five of the seven distributors with at least one Norwegian movie in cinemas at the point of closing. One of the interviews was conducted by email, one by phone and the others by video-meeting. At least of one the distributors has requested anonymity, none of the sources are named in this article.

Cinema attendance figures for titles playing in Norwegian theatres is publicly shared and, for this article, have been accessed through the Filmweb.no portal. No VOD numbers were publicly shared, although some informants provided ballpark figures. Filmweb is also the source of cinematic premiere dates. There is no official calendar for VOD releases and these have been collected through observation and, occasionally, from informants.

Visibility for Norwegian films on VOD platforms, as well as iTunes Top Chart positions, has been tracked through weekly visual observation. These observations were possible as they had been ongoing since August 2019 as a part of my doctoral thesis. While it would have been relevant for this article to also consider the releases and visibility for foreign titles as well, the nature of these digital platforms made it impossible to gather data about how they presented titles in the past.

For this article the platforms observed have been the Norwegian pages of international platforms iTunes and Google Play, the Norwegian pages of Scandinavian platforms Viaplay Store and Blockbuster, and the Norwegian services Get ${ }^{4}$ and Altibox.

iTunes, Google Play, Blockbuster and Viaplay Store are all TVOD/EST platforms for which titles are bought or rented individually. Get and Altibox are services provided

Teliaplay was untli 16.09.2020 known as Get, and the name change reflects that the cable operator Get was bought by Telia in 2018 . 
by cable companies. Get offers TVOD and SVOD titles, and Altibox offers EST, TVOD and SVOD titles.

For the purposes of this article, every instance of every Norwegian title on the front page has been noted in a spreadsheet. While it would have been desirable to also consider the level of visibility of each observation within the platform, this approach would create numerous methodological challenges that are outside the scope of this article.

\section{CLOSING TIME}

Several Norwegian distributors had titles either playing in cinemas when they were closed or slated to premiere in the spring of 2020. Nordisk Film Distribusjon, a subsidiary of the Danish-based company, has been the leading company for local titles in the last decade, both in the number of titles and in the market share for local titles. At the point of closing, Nordisk had four movies in cinemas. The thriller The Tunnel (Tunnellen, Øie 2019), the youth oriented mythological action-drama Mortal (Torden, Øvredal 2020), the broad comedy Fools in the Mountains (Fjolls til fjells, Holmsen 2020) and the family-oriented WW2-drama The Crossing (Flukten over grensen, Helgeland 2020). The Tunnel had been a successful Christmas release and was, for all practical purposes, finished in cinemas but had still not been released to home entertainment. Fools in the Mountains and The Crossing had been doing well, but Mortal had floundered.

SF Studios, a subsidiary of the Swedish-based company, had released one local title, the diverse youth drama Chica Chile Norway (Alle utlendinger har lukka gardiner, Søderlind 2020). The film was less than a week into its release when cinemas closed, but was tracking towards a respectable 60.000 admissions. SF Studios has generally been one of the major distributors in Norway with a mix of high-profile Norwegian titles as well as being the local distributor for Sony and Warner.

Norsk Filmdistribusjon, the largest of the independent Norwegian distributors, had released two Norwegian titles; the animated children's movie Ella Bella Bingo
(Elleville Elfrid, Blakseht \& Mosvold 2020) and the stark documentary The Self Portrait (Selvportrettet, Olin, Høgset, \& Wallin 2020), about a recently-passed photographer with anorexia. Both were at the end of their expected cinematic life, and The Self-Portrait was likely in its final week.

Several smaller distributors also had Norwegian titles in cinemas or lined up for a spring release. Manymore was planning to release their first local title, the horror film All must die (All må dø, Greni 2020). Euforia was planning to release three documentaries, iHuman (Schei 2019), Stay (Vær her, Bergem 2020) and Kids Cup (Bortebane, Hatland 2020). Little Big Sister had released All that I am (Alt det jeg er, Grottjord 2020) a documentary about a child abuse survivor. Another World had released the arthouse title We are here Now (Vi er her nå. Halle 2020) and another arthouse title, Are you Leaving Already? (Skal dere gå allerede?, Hoel 2019), was scheduled for independent release.

All of these distributors also had international titles playing or slated to premiere during the spring of 2020.

\section{PHASE ONE: \\ WHEN AND HOW TO VOD}

On March 12 it was announced that all cultural events in Norway, including cinemas, were banned for at least 14 days. According to one informant "the politics began immediately." Distributors had to choose whether to go for VOD early, to wait and see, or to postpone releases.

For the Norwegian titles these decisions would likely have to be negotiated with the producer as most contracts specify a cinematic window. For most international titles the decision would be made in negotiation with the original rights holder or simply be decided by the international rights holder.

During the next weeks it became clear that cinemas would remain closed for an extended period of time. On March 24 the government declared that cinemas and other cultural events would be banned until April 13 and, on April 4, the ban was 


\begin{tabular}{|c|c|c|c|c|c|}
\hline Title & $\begin{array}{l}\text { Premiere } \\
\text { date }\end{array}$ & $\begin{array}{l}\text { Opening } \\
\text { weekend }\end{array}$ & $\begin{array}{l}\text { Closing } \\
\text { week }\end{array}$ & $\begin{array}{l}\text { Total admissions } \\
\text { at closing }\end{array}$ & Distributor \\
\hline The Tunnel & 25.12.2019 & 41333 & 231 & 219276 & $\begin{array}{l}\text { Nordisk Film } \\
\text { Distribusjon }\end{array}$ \\
\hline The Self-Portrait & 17.01 .2020 & 6092 & 199 & 28883 & $\begin{array}{l}\text { Norsk } \\
\text { Filmdistribusjon }\end{array}$ \\
\hline Ella Bella Bingo & 24.01 .2020 & 16626 & 1884 & 66207 & $\begin{array}{l}\text { Norsk } \\
\text { Filmdistribusjon }\end{array}$ \\
\hline The Crossing & 14.02 .2020 & 20629 & 11205 & 110622 & $\begin{array}{l}\text { Nordisk Film } \\
\text { Distribusjon }\end{array}$ \\
\hline Fools in the Mountains & 21.02 .2020 & 28688 & 12086 & 84399 & $\begin{array}{l}\text { Nordisk Film } \\
\text { Distribusjon }\end{array}$ \\
\hline Mortal & 28.02 .2020 & 5461 & 1673 & 9753 & $\begin{array}{l}\text { Nordisk Film } \\
\text { Distribusjon }\end{array}$ \\
\hline We are here now & 28.02 .2020 & 340 & 35 & 673 & Another World \\
\hline Chica Chile Norway & 06.03 .2020 & 13820 & 16658 & 18211 & SF Studios \\
\hline All that I am & 06.03 .2020 & 916 & 2357 & 4990 & Little Big Sister \\
\hline All Must Die & 13.03 .2020 & 0 & 223 & 398 & Manymore \\
\hline ¡Human & 13.03 .2020 & 0 & 1283 & 13278 & Euforia \\
\hline Stay & 17.04 .2020 & 0 & 38 & 883 & Euforia \\
\hline Are you leaving already? & 17.04 .2020 & 0 & 0 & 0 & Self-distributed \\
\hline Kids Cup & 05.05 .2020 & 0 & 0 & 0 & Euforia \\
\hline
\end{tabular}

TABLE 1. Norwegian titles in cinemas spring 2020, total admissions include previews.

\begin{tabular}{lllll} 
Title & PVOD & EST & TVOD & Distributor \\
\hline iHuman & 0 & 17 & 38 & Euforia \\
Fools in the Mountains & $\times$ & 40 & 73 & Nordisk Film Distribusjon \\
Chica Chile Norway & 30 & 52 & 21 & SF Studios \\
Ella Bella Bingo & $\times$ & 73 & 73 & Norsk Filmdistribusjon \\
The Self Portrait & $\times$ & 83 & 87 & Norsk Filmdistribusjon \\
Mortal & $\times$ & 94 & 105 & Nordisk Film Distribusjon \\
The Tunnel & $\times$ & 115 & 136 & Nordisk Film Distribusjon \\
The Crossing & $\times$ & $x$ & $\times$ & Nordisk Film Distribusjon \\
Alt that I am & 157 & & & Little Big Sister
\end{tabular}

TABLE 2. Releases window in days after cinema premiere for Norwegian Covid-19 affected titles

* In instances where different platforms released the title on different days the window is counted based on the first instance. 
extended to June 15 (Helsedirektoratet 2020, Statsministerens kontor 2020 b, Statsministerens kontor 2020a). ${ }^{5}$

Euforia was the first to go for VOD and iHuman was released as a PVOD title on several Norwegian VOD platforms on March 13, the film's original cinema date. Over the weekend it was also made available on Scandinavian VOD platforms, but was not released on iTunes until March 30 when it was released as an EST title. This became the first ever PVOD release of a Norwegian film.

Nordisk Film Distribusjon also moved quickly. Fools in the Mountains was released as an EST title on April 1. According to Nordisk this was "as early as we could be sure to deliver the actual files and material." Initially, Nordisk had also intended to move Mortal and The Crossing ahead. However, Mortal was released on June 1 and The Crossing on June 8. The Tunnel was released March 30, according to plans made before Covid-19.

Nordisk did not choose a PVOD solution for Fools in the Mountains, preferring an early EST-release. This made the title available on all platforms including iTunes from day one. However, some major Norwegian VOD platforms, such as Get, did not have support for EST titles. Here Nordisk opted to release the film as rental titles at the same price point as the EST on other platforms, effectively resulting in a same date PVOD and EST release.

For Fools in the Mountains, Nordisk also extended the period from EST/PVOD until rental to almost five weeks. The Crossing and Mortal were released in similar fashion, although the titles were available as a rental a more-common three weeks after the PVOD/EST release.

SF Studios soon followed with an April 6 release of Chica Chile Norway as a PVOD title, which again excluded iTunes. On April 27 it was released as an EST title. SF Studios did not follow Nordisk's model and pulled the title from platforms (including Get) that did not support EST titles.

The ban did not apply to drive-in events.
SF Studios chose a three-week EST window and on May 18 it was also made available as a TVOD title.

Norsk Filmdistribusjon released Ella Bella Bingo and The Self Portrait on April 6 and 9 respectively. This resulted in slightly shorter cinematic windows than usual in Norway, and quite a bit shorter than Norsk Filmdistribusjon's average release windows. The Self Portrait was given only four days from EST to TVOD, while Ella Bella Bingo was released in both formats simultaneously.

Little Big Sister released All That I Am as a mid-priced $\mathrm{VOD}^{6}$ on a dedicated webpage in August ${ }^{7}$ though it had been digitally available for schools and workplaces since April. None of the other Norwegian titles that were playing or slated to play in cinemas in the spring of 2020 have been given a $V O D$ release at the time of writing.

\section{PHASE TWO: \\ CINEMA (SLIGHT RETURN)}

Early in April, several drive-in cinemas began opening in several Norwegian cities. These were all temporary sites, as there are no permanent drive-ins in Norway (TV 2 2020). On May 7 cinemas and other cultural events were allowed to reopen but were limited to 50 people per screening and at least one-meter distance between ticket holders from different households (Kulturdepartementet 2020). ${ }^{8}$

The Norwegian Film Institute (NFI) made several changes in their support schemes to adapt to the changed situations. These changes included support for re-releasing titles in cinemas and letting VOD titles as well as cinematic releases be included in a scheme for supporting "quality" film imports (NFI 2020 b).

SF Studios returned to cinemas with Chica Chile Norway which did meaningful business during the summer. Nordisk Film Distribusjon returned with all their titles. The Crossing did considerably better

100 nok, as opposed to the tradtional rental price point of about 49 nok and the other PVOD titles that were priced at 139 to 189 nok

7 https://educationalstorytelling.com/no

8 This was earlier than the date given initially and was announced April 30. 
business than the others, though Fools in the Mountains also did well. Norsk Filmdistribusjon returned with Ella Bella Bingo, but The Self-Portrait went to national publicservice broadcaster NRK who screened it during the summer. iHuman was also screened by NRK during the summer, and both deals were likely made before Covid19. Euforia's other titles are still unreleased. Kids Cup had not been finished due to Covid-19 and both Kids Cup and Stay were moved to spring 2021 to avoid the potential pile-up during fall and to preserve their original launch plans.

Another World's We Are Here Now also returned to cinemas with very limited bookings, several of these with cast and crew in attendance (Alternativet Produksjon 2020). Manymore had wanted to release All Must Die in this period but the producer wanted to wait, partly because he considered the re-launch funding to be inadequate. The film is slated to premiere in December 2020 (Aalborg 2020)

Manymore did however release their biggest investment to date, the Canadian animated children's title Trouble (Roberts, 2019) as soon as the drive-in cinemas opened. With no new releases coming from the major distributors Trouble did well in the charts, dominated by re-released titles from major distributors and new titles from independent distributors.

Euforia also released the Danish Daniel (Ser du månen, Daniel, Oplev \& Bertherlsen 2019) at the end of May as a "Kinoklubben"-titlem ${ }^{9}$ but did not expect the bleak title to perform very well. The decision to release was heavily influenced by a desire to help cinemas expand their programming. While audiences might have gone for lighter titles, cinemas welcomed it and Daniel had, at one point, been playing in as many as 90 cinemas; more than twice what Euforia had expected from this title.

\section{PHASE THREE: THE NEW NORMAL}

On June 15 the attendance limit for cultural events was increased to 200 people. The distancing rules remained in place, however, which meant that few screens could fit 200 people. According to the industry organisation Film \& Kino, the total seating capacity of Norwegian cinemas was reduced from 82000 to 10000 (Statsministerens kontor 2020c, Film og Kino 2020).

It was now becoming clear to the distributors that the fall schedule was likely to be heavily affected by the pandemic as major international titles were being moved. The immediate attention was fixed on SF Studios and Børning 3 (Brœin 2020), the third instalment of a popular car racing series. Børing 3 was slated for August 13, and would have been the first Norwegian title of the fall season. However, this date was dependent on Tenet (Nolan, 2020) also distributed in Norway by SF Studios keeping its scheduled July 24 date.

As Warner kept moving the Tenet date, SF Studios kept pushing Børning 3 to keep a gap between the titles.

Are You Leaving Already? became the first new Norwegian title in cinemas when it was released as a self-distributed title June 19, though it made very little box office impact. However, SF Studios moved the children's film Twigson and the Seamonster (Knerten og Sjøormen, Undheim, 2020) ahead from its original September date to July 3. The film was already finished and SF Studios and the producer reasoned that, as fall was becoming tight and the summer offerings were drying up, it was a good idea to release it during the summer (Rushprint 2020a). This also was an unusual move in the sense that Norwegian movies very rarely open during the summer ${ }^{10}$.

Twigson and the Seamonster was followed by Norsk Filmdistribusjon who released Sisters: The Summer We Found Our Superpowers (Tottori! Sommeren vi var Norwegian title, and the first non-self distributted, released in week 27 since at least 2008. 


\begin{tabular}{lllll} 
Title & Rank & $\begin{array}{l}\text { Weeks } \\
\text { playing }\end{array}$ & Admissions & Distributor \\
\hline Onward & 1 & 14 & 32509 & Walt Disney Company Nordic \\
The Crossing & 2 & 13 & 14476 & Nordisk Film Distribusjon \\
The Gentlemen & 3 & 15 & 14031 & Norsk Filmdistribusjon \\
Trouble* & 4 & 13 & 9423 & Manymore \\
The Peanutbutter Falcon & 5 & 5 & 9423 & Another World Entertainment \\
Bloodshot & 6 & 15 & 6798 & UiP \\
The Invisible Man & 7 & 15 & 6414 & UiP \\
Parasite & 8 & 15 & 6053 & Arthaus \\
Brahms' Cure: The Boy ${ }^{*}$ & 9 & 2 & 5429 & Storytelling \\
Fools in the Mountains & 10 & 14 & 5344 & Nordisk Film Distribusjon \\
Chica Chile Norway & 11 & 14 & 5152 & SF Studios \\
Daniel* & 13 & 8 & 4775 & Euforia \\
Ella Bella Bingo & 25 & 14 & 2148 & Norsk Filmdistribusjon \\
The Tunnel & 28 & 10 & 1756 & Nordisk Film Distribusjon \\
Torden & 60 & 11 & 394 & Nordisk Film Distribusjon
\end{tabular}

TABLE. 3: Top 10 plus selected titles in Norwegian cinemas form March 13 to June 18, *indicates new release. 
alene, Ommundsen \& Salomonsen 2020), another Norwegian children's movie that had been moved ahead from an autumn date (Rushprint 2020b). Both titles did well in the charts and Twigson recorded the best opening weekend since March.

In September something similar to a normal fall schedule for Norwegian films resumed. There had been some reshuffling due to various Covid-19 related delays, but in total 13 titles were slated to release during the fall. This will bring the total number of Norwegian premieres in 2020 to twentythree (NFI 2020a). This is lower than the average of the last decade, but up from 2019 when twenty-one titles premiered. NFI also launched a campaign to return audiences to the cinemas (Nordisk Film \& TV Fond 2020).

Nordisk Film Distribusjon released the comedy Diana's Wedding (Dianas Bryllup, Blom 2020) September 11. Euforia released the documentary The Painter and the Thief (Kunstreren og tyven, Ree 2020) September 18 and Norsk Filmdistribusjon released the animated children's comedy Two Men and a Badger 2 - The Great Big Beast (Knutsen \& Ludvigsen 2 Det store dyret, Spaans \& Enger 2020) on September 25.

While Børning 3 producer John M. Jacobsen had stated that the film's release depended on a wider opening of cinemas, it was finally released on October 14 (Rushprint 2020c, Kinomagasinet 2020). According to John M. Jacobsen, the decision to release Børning 3 in cinemas was an act of "solidarity" after Netflix bought the rights to the movie. It will premiere there early in 2021 (Skrede, Bjørhovde, and Kifle 2020)

Despite reduced capacity, Børning 3 recorded the best opening weekend of 2020, outperforming the original Børning (Bræin 2014), but not Børning 2 (Bræin 2016). Two men and a Badger 2 is currently performing on track with the original Two men and a Badger (Knutsen og Ludvigsen \& den fæle Rasputin, Sivertsen \& Spaans 2015). Twigson and the Seamonster did slightly less than the previous instalment in the Twigson-series before it was released as an EST title 82 days after the cinema premiere and as a TVOD title three weeks later. ${ }^{11}$

\section{IMPACT OF EARLY VOD-RELEASES}

Even with limited access to actual VOD sales, it seems very likely that there was little to gain for Norwegian titles by going for early VOD releases. While informants report higher than usual VOD sales during the lockdown period and especially for titles released early, these fall far short of what a normal cinematic run would have provided.

Going to VOD early certainly gave $\mathrm{iHu}$ man extra press and bolstered its visibility across the Norwegian and Scandinavian platforms. The film had generally high viewership numbers for a documentary. iHuman was also a part of a package of 20 films offered for free by broadband and cable supplier Canal Digital to its Norwegian customers. According to Euforia it attracted a significant number of viewers here and was among the top 10 titles on the service (Viken filmsenter 2020). The number of plays, however, was well below the number of admission that would have been expected at cinemas.

On iTunes (generally considered by informants to be the most important VOD/ EST platform) iHuman was never featured on the front page at all. This likely caused its poor chart performance compared to The Self-Portrait which had a more regular release and was given some exposure on iTunes. While iHuman was featured more frequently and for a longer period of time than The Self-Portrait, the difference was not very significant ${ }^{12}$.

The early release of Fools in the Mountains did not result in higher visibility than the regular releases of The Tunnel or

11 Børning 3 opened at 82024, Børning 2 at 119362 and Børning at 76708. The previous entry in the Twigson series, Twigson the Explorer (Ekspedisjon Knerten, Riiser 2017) totaled 155584. The original Two men and a Badger totaled 226880.

12 The Self Portrait was given significant exposure on Nettkino, a Norwegian VOD platform where Euforias titles are currently not available. Nettkino owns Norsk Filmdistribusjon. Nettkino was not observed until late April, and has not been included in this article. T-WE, Canal Digital's VOD platform where iHuman was offered for free was not one of the observed platforms. 


\begin{tabular}{|c|c|c|c|c|}
\hline Title & Rank & $\begin{array}{l}\text { Weeks } \\
\text { playing* }\end{array}$ & Admissions & Distributor \\
\hline Børning 3 & 1 & 5 & 225963 & SF Studios \\
\hline Two men and a Badger 2 & 2 & 7 & 198772 & Norsk Filmdistribusjon \\
\hline Tenet & 3 & 10 & 181277 & SF Studios** \\
\hline $\begin{array}{l}\text { Twigson and } \\
\text { the Seamonster }\end{array}$ & 4 & 19 & 129032 & SF Studios \\
\hline Trolls: World Tour & 5 & 4 & 97339 & UiP \\
\hline After We Collided & 6 & 8 & 67910 & Nordisk Film Distribusjon \\
\hline Onward & 7 & 19 & 56647 & The Walt Disney Company Nordic \\
\hline Sisters & 8 & 18 & 55713 & Norsk Filmdistribusjon \\
\hline Trouble & 9 & 19 & 52647 & Manymore \\
\hline Diana's Wedding & 10 & 8 & 46240 & Nordisk Film Distribusjon \\
\hline The Painter and the Thief & 13 & 10 & 25869 & Euforia \\
\hline The Gentlemen & 17 & 19 & 19532 & Norsk Filmdistribusjon \\
\hline The Crossing & 20 & 19 & 15847 & Nordisk Film Distribusjon \\
\hline Chica Chile Norway & 31 & 15 & 9406 & SF Studios \\
\hline Daniel & 57 & 16 & 2833 & Euforia \\
\hline Ella Bella Bingo & 66 & 12 & 2273 & Norsk Filmdistribusjon \\
\hline iHuman & 84 & 7 & 938 & Euforia \\
\hline
\end{tabular}

TABLE 4. Top 10 plus selected titles in Norwegian Cinemas from June 19 to October 23. 


\begin{tabular}{|c|c|c|c|c|c|c|c|c|}
\hline Title & iTunes & $\begin{array}{l}\text { Google } \\
\text { Play }\end{array}$ & Blockbuster & $\begin{array}{l}\text { Viaplay } \\
\text { Store }\end{array}$ & Altibox & Get & Total & Distributor \\
\hline $\begin{array}{l}\text { Twigson and } \\
\text { the Seamonster (3) }\end{array}$ & 17 & 3 & 6 & 19 & 34 & 1 & 80 & SF Studios \\
\hline The Tunnel (4) & 6 & 4 & 6 & 14 & 9 & 3 & 42 & $\begin{array}{l}\text { Nordisk Film } \\
\text { Distribusjon }\end{array}$ \\
\hline $\begin{array}{l}\text { Fools in the } \\
\text { Mountains (5) }\end{array}$ & 5 & 6 & 5 & 14 & 15 & 4 & 49 & $\begin{array}{l}\text { Nordisk Film } \\
\text { Distribusjon }\end{array}$ \\
\hline The Crossing (6) & 18 & 2 & 14 & 23 & 19 & 7 & 83 & $\begin{array}{l}\text { Nordisk Film } \\
\text { Distribusjon }\end{array}$ \\
\hline The Self Portrait (9) & 3 & 0 & 0 & 0 & 3 & 4 & 10 & $\begin{array}{l}\text { Norsk } \\
\text { Filmdistribusjon }\end{array}$ \\
\hline Mortal (11) & 15 & 9 & 3 & 13 & 15 & 8 & 63 & $\begin{array}{l}\text { Nordisk Film } \\
\text { Distribusjon }\end{array}$ \\
\hline Ella Bella Bingo (11) & 7 & 2 & 0 & 0 & 1 & 3 & 13 & $\begin{array}{l}\text { Norsk } \\
\text { Filmdistribusjon }\end{array}$ \\
\hline Chica Chile Norway (16) & 9 & 6 & 6 & 20 & 3 & 2 & 46 & SF Studios \\
\hline iHuman (95) & 0 & 1 & 0 & 4 & 6 & 3 & 14 & Euforia \\
\hline
\end{tabular}

TABLE 5. Visibility of Norwegian Covid-19 films in the first five weeks after VOD release date. Highest noted position on iTunes Top Chart in parentheses 
The Crossing. Mortal also seems to have outperformed Chica Chile Norway in the home entertainment markets, despite Chica Chile Norway's far better opening weekend and early release.

Even very limited cinematic exhibition seems to have been more valuable for Norwegian films than a relatively high-profile VOD-release. This is likely to be particularly true for global platforms such as iTunes that would not or could not react quickly to the requests from Norwegian distributors. The case of iHuman particularly highlights the very different experiences of working with global versus local VOD platforms (Viken filmsenter 2020).

However, at least during this particular moment in time, it did not seem to hurt the cinematic attendance of titles such as The Crossing, Chica Chile Norway or Onward that they were also available on VOD, suggesting that early releases might not cannibalise attendance in the way cinemas tend to fear.

Several informants said that keeping good working relations with producers, directors and cinemas was a key part of their decisions in the period. Not only did it influence their decision when and how to release VOD titles, but also their decision to release new titles to the cinemas even if they were not expected to do well.

\section{CONCLUSION}

There is no doubt that the Covid-19 crisis has hit Norwegian distributors hard. Several companies had to furlough staff. However, none have expressed worries about their imminent survival. One informant was more concerned about the production companies, expressing concern that even if they were able to deliver their films, they would have incurred such heavy costs due to the delay that they would be forced into bankruptcy.

The strategic responses of Norwegian distributors would be best described as damage limitation. While several informants indicate that they have gained valuable information from experiments, it seems that keeping good relations with cinemas and producers has been more important than breaking new ground. There are currently no indications that the PVOD/early releases of March 2020 will be repeated in the immediate future.

The Norwegian titles that were released early on VOD faced very strong competition for attention by several Hollywood titles released in a similar fashion, but Norwegian films have struggled to gain market shares in the digital home markets for years (Gaustad et al. 2018) and as long as this remains an underlying problem it seems unlikely that changes in window strategies will have any major effect on the bottom line.

While cinema attendance by the end of September 2020 had been more than halved compared by the same time period in 2019, Norwegian titles are now claiming a significant share of the attendance.

At the end of October 2020 the marketshare for Norwegian movies in 2020 is a record-breaking $29.9 \%$ and, since June 19 , an astounding $41.4 \%$.

Though Norwegian films like Børning 3, as well as the upcoming Troll (Uthaug, 2022) and Battle: Freestyle (Søderlind, 2021) have been purchased by SVOD services such as Netflix (Ramachandran 2020, Netflix 2020), there are still no indications that VOD can become a viable alternative to cinema, even at reduced capacity, for most Norwegian movies.

\section{ACKNOWLEDGMENTS}

I would like to thank the anonymous peer reviewers for insightful comments, and to everyone l've interviewed for this article. You know who you are. 


\section{BIBLIOGRAPHY}

Aalborg, Helene. 'Den uavhengige filmens d $\varnothing d$ ?' Rushprint, 30 November 2020. https://rushprint. no/2020/11/den-uavhengige-filmens-dod/. Alternativet Produksjon. 2020. 'VI ER HER NÅ'. Alternativet. 2020. https://www.alternativetproduksjon. no/vi-er-her-n

Bakøy, Eva, Roel Puijk, and Tore Helseth, eds. 2016. Bak kamera: norsk film og TV i et produksjonsperspektiv. Vardeserien. Vallset: Oplandske bokforl.

Crisp, Virginia. 2015. Film Distribution in the Digital Age: Pirates and Professionals. Basingstoke, Hampshire: Palgrave Macmillan

Film og Kino. 2020. 'Hvordan måle en meter i en kinosal?’ 2020. https://www.kino.no/article1432447.ece. Gaustad, Terje, Leo A Grünfeld, Audun Engelstad, Dombu, Siri Voll, Flesche, Bjørn I, and Lind, Lars Hallvar. 2020. 'Evaluering Av Tilskuddsordninger På Filmområdet'. Kulturdepartementet. https://www. regjeringen.no/contentassets/c9e4d8ed85874a7dab0c5a67ba1ec6a2/rapport---evaluering-filmpolitiskeordninger-menon-2019.pdf.

Gaustad, Terje, Theie, Marcus Gjems, Irina

Eidsvold-Tøien, Øyvind Torp, Anne-Britt Gran, and Anne Espelien. 2018. 'Utredning Av Pengestrømmene I Verdikjeden for Norske Filmer Og Serier'. 5/2018. Menon-Publikasjon. Oslo: BI: Center for Creative Industries. https://www.regjeringen.no/contentasset s/98eb45b476284d5c8ef97ffe7c13392b/prm-8-18vedlegg-rapporten.pdf.

Helsedirektoratet. 2020. 'Helsedirektoratet har vedtatt omfattende tiltak for å hindre spredning av Covid-19'. 12 March 2020. https://www.helsedirektoratet.no/ nyheter/helsedirektoratet-har-vedtatt-omfattendetiltak-for-a-hindre-spredning-av-covid-19\#stengingog forbudavulikearrangementerogtilbud.

Hjort, Mette, and Duncan J. Petrie. 2007. The Cinema of Small Nations. Edinburgh: University Press. Ide, Wendy. 2020. 'The Future of Film: Can Cinema Survive Covid-19?' The Guardian: Film, 7 December 2020. http://www.theguardian.com/film/2020/jul/12/ the-future-of-film-can-cinema-survive-covid-19. Kinomagasinet. 2020. 'Vurderer å utsette Børning 3 KM', 11 August 2020. http://www.kinomagasinet.no/ artikkel/vurderer-a-utsette-borning-3/.

Kulturdepartementet. 2020. 'Nye råd og retningslinjer for arrangementer'. Pressemelding. Regjeringen.no. regjeringen.no. 30 April 2020. https://www.regjeringen. no/no/aktuelt/nye-rad-og-retningslinjer-for-arrangementer/id2700784/.

Lotz, Amanda D. 2019. 'Teasing Apart Television Industry Disruption: Consequences of Meso-Level Financing Practices Before and After the US Multiplatform Era: Media, Culture \& Society 41 (7): 923-38. https://doi.org/10.1177/0163443719863354.

McClintock, Pamela. 2020. 'Skipping Theaters? Hollywood Studios Weigh Risks of PVOD I Hollywood Reporter'. The Hollywood Reporter, 23 October 2020. https://www.hollywoodreporter.com/news/skippingtheaters-hollywood-studios-weigh-risks-of-pvod. Netflix. 2020. 'About Netflix - BATTLE IS BACK! Netflix Announces Battle: Freestyle, a Sequel to the Norwegian Dance Feature Battle'. About Netflix. 2020. https://about.netflix.com/, https://about.netflix.com/ en/news/battle-is-back-netflix-announces-battlefreestyle-a-sequel-to-the-norwegian.

NFI. 2020a. 'Her er den norske filmhøsten 2020'.

NFI. 2020. https://www.nfi.no/aktuelt/2020/

her-er-den-norske-filmhosten-2020.

NFI. 2020b. 'Nye tiltak fra NFI'. NFI. 2020.

https://www.nfi.no/covid19/nye-tiltak-fra-nfi.

Nordisk Film \& TV Fond. 2020. 'Norwegian Film Institute Injects NOK $3.5 \mathrm{~m}$ in Cinema Campaign'. Nordisk Film \& TV Fond. 2020. https://www.nordiskfilmogtvfond. $\mathrm{com} /$ news/stories/norwegian-film-institute-injectsnok-3-5m-in-cinema-campaign.
Ramachandran, Naman. 2020. 'Netflix Sets "Troll" from "Tomb Raider" Director Roar Uthaug'. Variety. 25 August 2020. https://variety.com/2020/streaming/global/ netflix-troll-roar-uthaug-norway-1234747665/. Rushprint. 2020a. 'Knerten kommer kinoene til unnsetning'. Rushprint. 8 June 2020. https://rushprint. no/2020/06/knerten-kommer-kinoene-til-unnsetning/. _- - 2020b. 'Filmsamtalen med Silje Salomonsen og Arild Ø. Ommundsen'. Rushprint. 6 August 2020. https://rushprint.no/2020/08/filmsamtalen-medsilje-salomonsen-og-arild-o-ommundsen/.

- - 2020c. 'Er den norske kinohøsten klar for 13 premierer?' Rushprint. 11 August 2020. https:// rushprint.no/2020/08/er-den-norske-kinohostenklar-for-13-premierer/.

Skagen, Sølve. 2020. '- Hva er galt med publikumsfrieri, om du får et rungende ja fra den du frir til? (+)'. Rushprint. 29 October 2020. https://rushprint.no/2020/10/ hva-er-galt-med-publikumsfrieri-om-du-far-et-rungende-ja-fra-den-du-frir-til/.

Skei, Caroline Strutz. 2010. 'Hollywood in Norway Distribution and Repertoire.' Master Thesis in Media Studies, University of Oslo.

Skrede, Mone Celin, Hilde Bjørhovde, and Mylena Kifle. 2020. 'Kinoene sliter. Høstens store norske film holdt på å havne rett på Netflix: - Vi valgte kino i solidaritet'. Aftenposten, 20 October 2020. https://www. aftenposten.no/kultur/i/aPwL42/besoeket-er-halvertstorfilmer-utsettes-stroemmetjenestene-ruster-opp. Statsministerens kontor. 2020a. 'Tiltakene mot koronavirus videreføres'. Pressemelding. Regjeringen.no. 24 March 2020. https://www.regjeringen.no/no/aktuelt/ tiltakene-mot-koronavirus-viderefores/id2694682/. _- _. 2020b. 'Vil åpne samfunnet gradvis og kontrollert'. Pressemelding. Regjeringen.no. 7 April 2020. https://www.regjeringen.no/no/aktuelt/Vil-apnesamfunnet-gradvis-og-kontrollert/id2697060/. _- - 2020c.'Regjeringens plan og justering av koronatiltak. Pressemelding. Regjeringen.no. 7 May 2020. https://www.regjeringen.no/no/aktuelt/ regjeringens-plan-og-justering-av-koronatiltak/ id2701493/.

TV 2. 2020. 'Åpner gigantisk «drive-in-kino» på Fornebu'. TV 2. 7 April 2020. https://www.tv2.no/a/11358976/. Viken filmsenter. 2020. 'Publikumsarbeid i Koronaens tid'. 2020. https://vikenfilmsenter.no/publikumsarbeidi-koronaens-tid-2/. 